Clim. Past Discuss., doi:10.5194/cp-2017-42, 2017

Manuscript under review for journal Clim. Past

Discussion started: 3 April 2017

(C) Author(s) 2017. CC-BY 3.0 License.

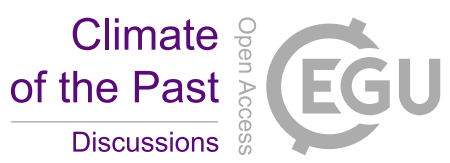

\title{
Permian Megamonsoon Sensitivity to Paleo-Tethys Warm Pool: Model Simulations using CCSM3
}

\author{
Christine A. Shields ${ }^{1}$ and Jeffrey T. Kiehl ${ }^{1}$ \\ ${ }^{1}$ National Center for Atmospheric Research, Boulder, Colorado, 80307 \\ 5 Correspondence to: Christine A. Shields (shields@ucar.edu)
}

\begin{abstract}
Simulations of the late Permian (251Ma) are analyzed with respect to the northern hemispheric Pangean megamonsoon. We find that the presence and spatial distribution of the warm pool, and not land-sea temperature differences, are the primary forcing agents for the megamonsoon. The land-sea temperature gradient, as a monsoonal mechanism, is tested by eliminating the Cathyasian peninsula and is found to have little impact on the spatial character of the monsoon.

10 Furthermore, the response of the monsoon to the warm pool was tested by removing all Paleo-Tethys equatorial islands, which allows the warm pool to expand and migrate westward thus shifting the pattern of monsoonal precipitation. Additionally, different $\mathrm{CO}_{2}$ regimes are presented, in which a 10 -fold change in forcing produces diverging climates and therefore different warm pool and monsoon locales. Atmospheric mass flux for the monsoonal regime is characterized and shown to change with warm pool movement. Tropical and equatorial ocean currents impact the seasonal progression and

15 location of the warm pool. Experiments were conducted using the low-resolution version of Community Climate System Model, Version 3 (CCSM3) in both coupled and fixed sea surface temperature (SST) context. For validation purposes, a modern control is briefly presented with observations and is shown to represent both the spatial and seasonal progression of the Indian monsoon.
\end{abstract}

\section{Introduction}

The nature of monsoons has been studied extensively in the scientific community because of its significance in dominating regional weather and climate and its impact on society. Computer models have long been used as a tool to diagnose, predict, and understand the physics behind the monsoon for present day as well as for climates of the past. Specifically, simulations of the Pangean megamonsoon have been used to infer the monsoonal climate regime and cross referenced with proxy data

25 (e.g. Kutzback and Gallimore 1989, Fluteau et al 2001, Kutzback and Ziegler 1993, Rowe et al 2007). Analyzing the underlying mechanisms behind the monsoon in past climates gives us a deeper understanding of what drives the present-day monsoon. In this study, we use the low-resolution Community Climate System Model (CCSM3) (Collins et al 2006), to 
Clim. Past Discuss., doi:10.5194/cp-2017-42, 2017

Manuscript under review for journal Clim. Past

Discussion started: 3 April 2017

(C) Author(s) 2017. CC-BY 3.0 License.

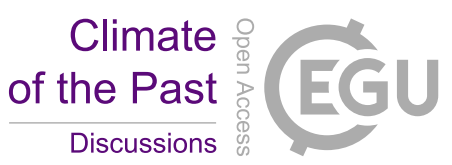

analyze the monsoon in the latest Permian (251 Ma). Although Meehl et al (2006) discuss the world's monsoons in the standard resolution CCSM3, we present additional support that the low-resolution version of CCSM3 is suitable for this study. Other independent studies on the Permian monsoon using the low resolution CCSM3 have been published, but with the emphasis on orbital variations and their impact on the biogeochemistry (Winguth and Winguth (2012) as well as 5 implications for glaciation (Heavens et al 2015).

Earth experienced its greatest mass extinction at the Permian-Triassic (PT) boundary (251Ma), (e.g. Erwin 1993, Wignall and Twitchett 1996) where $90-95 \%$ of ocean species and 70\% of terrestrial life was lost. Elevated levels of $\mathrm{CO}_{2}$, anoxic oceans, and intense volcanic activity are believed to have been major factors in this mass extinction event, (Black et al, 2012,

10 Kidder and Worlsely 2004, Benton and Twitchett, 2003, Berner 2002, Renne et al, 1995, Erwin 1993). Results from Kiehl and Shields (2005) (KS2005) show the fully coupled model, CCSM3, support both the current extinction hypotheses and available observational record by simulating warm high latitude surface air temperature and a stagnate global ocean circulation. In this sensitivity study, we include a series of additional CCSM3 simulations designed to highlight the importance of the Paleo-Tethys oceanic warm pool and its impact on the Permian megamonsoon.

15

\section{Model and Experimental Design}

The fully coupled Community Climate System Model (CCSM3) has been successfully implemented for a wide range of past climates spanning deep time through the Quaternary and modern periods, (e.g., Kiehl and Shields, 2013, Zhou et al. 2012, Herold et al 2011, Herold et al 2012, Jochum et al 2009, Shellito et al 2009, Larmarque et al 2006, Otto-Blieser et all

$202006 \mathrm{a} / \mathrm{b}$, Lui et al 2003). For paleoclimate simulations, given the necessity for long equilibrium coupled model runs, the low-resolution version of CCSM3 is utilized. The low resolution CCSM3 (Yeager et al, 2006) provides a realistic climate solution at a significant reduction in computer cost. Table 1 summarizes the various simulations analyzed for this paper. All PT runs use the same boundary and forcing data found in KS2005 except for where noted in Table 1. Table 2 describes KS2005 forcing data. Further details on experimental design and CCSM3 can be found in Appendix A. 
Clim. Past Discuss., doi:10.5194/cp-2017-42, 2017

Manuscript under review for journal Clim. Past

Discussion started: 3 April 2017

(c) Author(s) 2017. CC-BY 3.0 License.

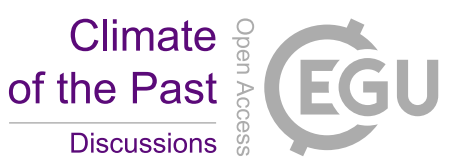

\section{Climate and Monsoon State}

\subsection{The atmosphere}

Figure 1 shows the winter (DJF) and summer (JJA) surface temperatures for the standard PT paleogeography and the modern coupled simulations, 10xPT_C, 1xPT_C, and Mod_C. In the 10x case, surface temperatures are generally $10-20{ }^{\circ} \mathrm{C}$ warmer

5 than present day in the northern hemisphere summer over land with annual ocean temperature differences ranging from a few degrees near the equator to 6-8 degrees in the mid to high latitudes (Kiehl and Shields, 2005). In particular, northern hemisphere surface temperatures over the 10x Permian monsoon region, approximately 9-21N and 90-150E, compared to the present day Indian monsoon region show differences around 6 degrees C. As expected, the 1x Permian is much colder than the 10X Permian due to the lower $\mathrm{CO}_{2}$ values and the lower solar forcing found in the Permian period. Unlike the 10x case,

10 the $1 \mathrm{x}$ case grows considerable amount of ice in both hemispheric polar regions with the northern hemisphere ice extent extending well into the mid-latitudes. Compared to present day, annually averaged temperatures in the $1 \mathrm{x}$ case are slightly cooler than present day everywhere except the poles. However, in the monsoon region, surface temperatures are actually quite similar to present day. The seasonal cycle of isolation in the northern hemisphere is similar between the Permian and modern periods such that the peak in solar heating for monsoonal regions occurs in the Boreal summer months. Seasonal

15 cycles of precipitation are calculated and plotted for monsoonal regimes for the 10x, 1x, and modern simulations along with present day observations (Global Precipitation Climatology Project, GPCP, Yin et al 2004) (Figure 2). The Indian monsoon is the closest comparison to the PT megamonsoon and is therefore used for the modern and observational plots. Precipitation seasonality in both Permian cases is shifted one month and peaks in August rather than July as seen in the modern simulation and observations. Spatial and temporal similarities between the modern simulation and observations allows us to confidently

20 assess the Permian monsoon in CCSM3. Although both 10x and 1x cases peak in August, the 10x case has far more precipitation and a different spatial locale for the maxima. The $1 \mathrm{x}$ case is clearly shifted eastward to $150 \mathrm{E}-200 \mathrm{E}$. It is our assertion that the monsoon, and hence maximum precipitation area, follows the warm pool rather than the land/sea temperature gradients across the peninsula and will be discussed further in section 4. Another atmospheric diagnostic typically used to identify monsoon regions is the velocity potential. Both the $10 \mathrm{x}$ and $1 \mathrm{x}$ simulations exhibit upper level divergence and surface convergence areas in the Permian monsoon region typical of a monsoon response (not shown). 
Clim. Past Discuss., doi:10.5194/cp-2017-42, 2017

Manuscript under review for journal Clim. Past

Discussion started: 3 April 2017

(C) Author(s) 2017. CC-BY 3.0 License.

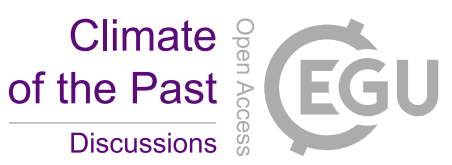

(c) $\underset{\mathrm{BY}}{(i)}$

\subsection{The ocean}

From Figure 1 we infer differences in the warm pool for Boreal summer. A closer look at the PT megamonsoon region in Figure 3 highlights the changes in character to the warm pool as it has evolved over the warm months. The dominant SST peak for the monsoon region in the $1 \mathrm{x}$ case is now later in the season and spatially shifted eastward with its maxima now

5 located $\sim 205 \mathrm{E}$. Although the two cases are similar in terms of structure, it is clear the position of the SST warm pool has shifted.

Ocean circulation appears to be affected as well. Figure 4 shows the vertical velocities of the Permian oceans in both winter and summer for both cases. The waters surrounding the northern hemisphere peninsula in the Paleo-Tethys Sea and west

10 Panthalassic Ocean in Boreal winter are predominately sinking due to colder seasonal SSTs. The 1x case, a colder simulation, shows increased widespread sinking (Figure 4 upper right). Boreal summer velocities in both simulations exhibit widespread upwelling due to warm and fresh waters (in part, due to the intense bands of precipitation). Saltwater fluxes (not shown) also confirm the upwelling and fresh nature of these areas during the monsoon season. The 10x case has a more localized response to the monsoon than the $1 \mathrm{x}$ case, which is more diffuse, illustrated by the broad upwelling band from 150-

$15210 \mathrm{E}$ (Figure 4 lower panels).

\section{Removing the Cathyasian Peninsula}

To test the warm pool hypothesis, we ran an atmosphere-only CAM3 simulation where we removed the Cathyasian peninsula geographically located at the heart of the PT megamonsoon in the 10x coupled simulation. The new geography and land-seas boundaries can be seen in Figure 5 (left panels). (The slight differences in the continental boundaries between

20 the CAM stand-alone run and the CCSM3 coupled run are due to technical issues related to the communications between the oceanic and atmospheric grids. These differences have no impact on the climate results). Figure 5 compares the DJF and JJA precipitation for both 10xPT_C and 10xPT_F_NoPen. DJF precipitation does not alter dramatically, as expected because this is wintertime for the northern hemisphere and the Permian monsoon is not present. For JJA, Boreal summer, precipitation still does not change significantly in spatial organization. Even with the peninsula land removed, the 
Clim. Past Discuss., doi:10.5194/cp-2017-42, 2017

Manuscript under review for journal Clim. Past

Discussion started: 3 April 2017

(c) Author(s) 2017. CC-BY 3.0 License.

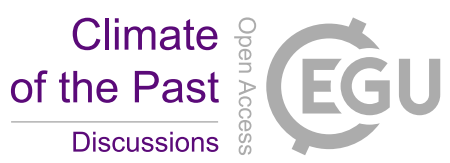

(c) $\underset{\mathrm{BY}}{(i)}$

"monsoon" precipitation does not change in character, indicating that the underlying and primary forcing for the monsoon is unrelated to the land-sea surface temperature gradients. This forcing is not unique to the Permian world. Chao and Chen (2001) found that for continental regions not directly impacted by the ITCZ, the monsoon is not impacted by removal key land masses and therefore the surface temperature gradients. Specifically, they found that when the Indian and Asian

5 subcontinents were removed, (similar to our removal of the Permian northern hemisphere peninsula), the monsoons were still in tact.

These findings support our hypothesis that the Permian monsoon is driven by the location of the warm pool and not land-sea gradients. This idea is also supported in CAM3 aqua-planet simulations (personal communication, David Williamson). In

10 the aqua-planet experiments, the surface temperatures were perturbed slightly at various locations on the globe. Precipitation maxima consistently form along the perturbed (increased) surface temperature areas. We are able to compare 10x coupled case (10xPT_C) to the fixed SST PT control (10xPT_F) because 10xPT_F successfully reproduces the climate of 10xPT_C, and, specifically, retains the spatial and seasonal integrity of the PT megamonsoon (not shown).

15 The monsoon is not entirely defined by precipitation; there are many other variables available to analyze monsoon behaviors. Mass flow into convergence areas and subsequent rising air mass and upper level divergence can be used to mark monsoon regions. To assess the atmospheric dynamics related to monsoonal circulation, the seasonal cycle of velocity potential is shown for 10xPT_C, 10xPT_F, 10xPT_F_NoPen (Figure 6). We look at the fixed SST PT control (10xPT_F), in part, to further convince ourselves the atmospheric climate solution, specifically the dynamics (and hence monsoon forcing) of the

20 CAM3 Permian world produces a similar solution to the CCSM3 coupled Permian world (Figure 6, upper and middle panels). The lower panel of Figure 6 illustrates the minimal impact on the dynamics by removing the Cathyasian Peninsula. Lower level convergence (and consequently upper level divergence) in the eastern hemisphere monsoon region displayed in all 3 panels exists with minimal differences. The strongest convergence area, however, is over the desert region of Pangea and not the monsoon region. The mechanism here is simply a response to the thermal heating of extreme heat associated 
Clim. Past Discuss., doi:10.5194/cp-2017-42, 2017

Manuscript under review for journal Clim. Past

Discussion started: 3 April 2017

(C) Author(s) 2017. CC-BY 3.0 License.

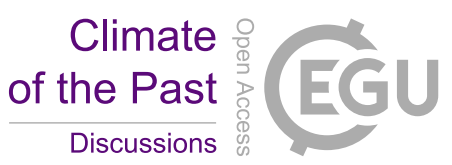

with desert land types (Kiehl and Shields 2005). It is important to note the distinction between the thermal heating forcing over the deserts and the latent heating generated by the SST warm pool heating over the monsoon region.

\section{Removing Paleo-Tethys Equatorial Islands}

Removing the Cathyasian Peninsula in a fixed SST simulation provides a computationally inexpensive way to test if the

5 monsoon precipitation was indeed related to the underlying SSTs, or the land mass surface temperature gradients. We have shown thus far the warm pool to be the mechanism responsible for driving the atmospheric precipitation patterns. To continue along this theme and test changes in the monsoon patterns in a fully coupled context, we designed a CCSM3 experiment to allow the oceanic warm pool to migrate unbounded by tropical and subtropical land masses in the Panthalassic Ocean. Allowing ocean currents to change in response to the absence of the Paleo-Tethys equatorial islands, in addition to excluding the Cathyasian Peninsula, will further demonstrate how warm pool mechanism operates in a dynamic sense, i.e. allow the monsoon precipitation to move with the warm pool.

\subsection{SST and Precipitation Response}

10xPT_C_NoIsle was integrated for 200 years, which is sufficient to allow both the atmospheric solution and upper ocean currents and temperatures to reach equilibrium. The monsoon precipitation does indeed follow the warm pool, in fact, the

15 SST warm pool not only migrates landward, it clearly expands in all directions and in all seasons. Specifically, in Boreal summer, the warm pool expands primarily north and west but also expands somewhat into the southern hemisphere tropical band as seen in Figure 7 (upper and middle panel). The lower panel of Figure 7 shows the precipitation differences between the no-island sensitivity simulation and the original fully coupled simulation and demonstrates the northern hemispheric monsoonal precipitation maximum has shifted landward with the migrating warm pool. Another interesting shift in

20 precipitation occurs in the southern hemispheric equatorial band between 40E - 120E just off the Pangean coast. This shift in precipitation is largely due to the increase in the JJA southern easterlies (and alterations in the ITCZ), which occurs with the absence of the equatorial islands. In the original simulation, these islands serve as a barrier to the southeasterly flow and provoke convection related to localized surface convergence zones (Figure 5). Without these islands, this band of summertime precipitation redistributes itself more evenly across the southern equatorial latitude band. 
Clim. Past Discuss., doi:10.5194/cp-2017-42, 2017

Manuscript under review for journal Clim. Past

Discussion started: 3 April 2017

(c) Author(s) 2017. CC-BY 3.0 License.

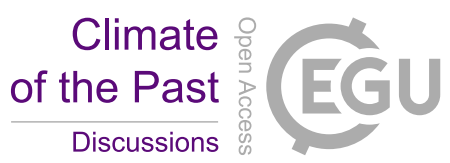

In addition to the spatial expansion of the warm pool, we see changes in the seasonality of the monsoon as well. Figure 8 is a Hovmueller diagram of the SST averaged over the PT megamonsoon region 9-21N. We have extended the longitudinal range to $60 \mathrm{E}-220 \mathrm{E}$ (compared to Figure 2) to highlight the expansion area in the no-island experiment. Again, we can see the

5 spatial expansion in the longitudinal direction as described earlier in the section. The warmest SSTs now reach eastward of $90 \mathrm{E}$ in the summer months and even to $60 \mathrm{E}$ in June. Interestingly, the most dramatic expansion occurs in the fall where SSTs not only increase by nearly 2 degrees C in September and October in the 90E-180E longitude band. The precipitation follows suit as seen in Figure 9. The precipitation maximum has is now centered about 90E and peaks in July instead of August, and the seasonal progression also changes character somewhat and now has a distinct secondary precipitation maximum in October.

\subsection{Dynamical Responses}

In order to best assess the atmospheric dynamic changes in the no-island simulation, we again look at JJA $850 \mathrm{mb}$ velocity potential. Figure 10 shows the changes in surface convergence and subsequent mass flux patterns between the no-island and original simulations. We see a strong increase in the southern hemisphere that reflects the general expansion of the warm

15 pool into the southern hemisphere. The no-island velocity potentials are much larger in the equatorial band without the presence of land masses that tend to increase friction and slow the wind.

For the ocean's dynamical response, we turn to the annual mean ocean undercurrent about the equator for the Paleo-Tethys and Panthalassic Oceans in Figure 11. The obvious impact of removal of the equatorial islands is evident in the extension of 20 the equatorial undercurrent to the eastern Paleo-Tethys at 30E. Again, the breaks in the original simulation in Figure 11 (upper panel) indicate land locations. The western Panthalassic remains relatively unchanged. The undercurrent has flattened and expanded land(west)ward and thus serving to redistribute the waters in the top $500 \mathrm{~m}$ and preventing sea surface heights from increasing. The undercurrent does not extend all the way to land $(\sim 10 \mathrm{E})$ because of the increased coastal surface winds and ocean stresses directly lee of Pangea from $30 \mathrm{~N}$ to $30 \mathrm{~S}$. These surface stresses also serve to advect cooler 
Clim. Past Discuss., doi:10.5194/cp-2017-42, 2017

Manuscript under review for journal Clim. Past

Discussion started: 3 April 2017

(C) Author(s) 2017. CC-BY 3.0 License.

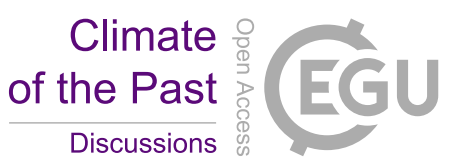

waters equatorward directly along the coast thus preventing the SST warm pool from ultimately reaching the coast as well (not shown).

The equatorial islands impact on the ocean currents can also be examined in the context of vertical velocities due to salinity

5 changes. We noted in section $5 \mathrm{a}$ that the presence of the equatorial islands was responsible for the localized band of precipitation about the equator. Removing the islands induce a redistribution of the precipitation along the ITCZ, and, consequently alterations upper ocean salinity. We generally see a saltier Paleo-Tethys and western Panthalassic and a gentler halocline leeward of the largest island $(\sim 100 \mathrm{E})$. Upper ocean vertical velocity changes in the monsoon and equatorial regions are, in part, a direct reflection of these salinity and precipitation changes.

\section{Conclusions}

For the latest Permian period, the location of SST warm pool and not the "classic" land-sea surface temperature gradient is the governing factor in defining the megamonsoon. By examining three separate sensitivity experiments we show that as the Paleo-Tethys oceanic warm pool moves, so does the monsoonal precipitation. By altering the PT paleogeography (10xPT_C_NoIsle and 10xPT_F_NoPen), as well as lowering $\mathrm{CO}_{2}$ values $(1 \mathrm{xPT} C$, thereby changing the climate and ocean 15 circulation), two distinct approaches are applied to force a change in the megamonsoon. Removing the Cathyasian Peninsula has a minimal impact on the spatial precipitation patterns. The precipitation maxima remain in roughly the same location, but with no nearby land, thus eliminating a land-sea gradient as a potential monsoonal mechanism. Removing the equatorial islands allows the ocean currents to change, shift and expand the warm pool, and consequently, the shift and expand the precipitation maxima locale. The paleogeography experiments are reinforced by examining the monsoon in the low $\mathrm{CO}_{2}$ simulation where the Paleo-Tethys warm pool is in a different location compared to the original high (10x) $\mathrm{CO}_{2}$ simulation. Atmospheric mass flux patterns confirm dynamical shifts in response to the warm pool movement. These shifts do not occur in the absence of the Cathyasian Peninsula and associated land-sea gradients. Once all the equatorial islands are removed, the character of the precipitation is also changed for areas near the equator and along the ITCZ. Despite the relatively small size of the Paleo-Tethys islands, it is clear that these land masses have a dramatic effect on local precipitation, salinity, and 
Clim. Past Discuss., doi:10.5194/cp-2017-42, 2017

Manuscript under review for journal Clim. Past

Discussion started: 3 April 2017

(c) Author(s) 2017. CC-BY 3.0 License.

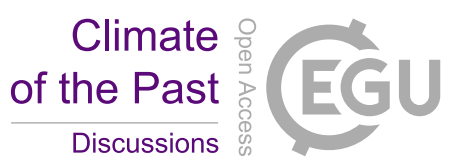

ocean currents. When the SST warm pool is allowed to expand, it not only moves the monsoon, but also changes the nature of equatorial convective cells associated with the ITCZ. Peak precipitation occurs earlier in July compared to the original paleogeography experiments where the peak occurs in August. The redistribution of precipitation, and thereby salinity, in response to the lack of islands, affects the upper ocean currents in concert with the flattening and expansion of the equatorial

5 undercurrent. It is clear that both atmospheric and oceanic components, and the interplay between the two, are important when defining the monsoon. For Permian geography, the tropical and equatorial ocean currents govern the seasonal progression and location of the warm pool, which in turn affect atmospheric winds, convergence zones, and precipitation bands. All of these processes ultimately define the megamonsoon.

\section{Appendix A: Model and Experiment Details}

10 The atmosphere and land model components are defined by a T31 horizontal grid $\left(3.75^{\circ} \times 3.75^{\circ}\right.$ spectral truncation) with 26 atmospheric vertical levels. The ocean and ice components are defined by a nominal $3^{\circ}$ horizontal grid with 25 oceanic vertical levels. Description and validation of the modern CCSM3 control can be found in Yeager et al 2006, which uses standard present day forcing and boundary data. A modern control was used instead of a pre-industrial simulation to validate with available observational datasets.

15

The original PT CCSM3 fully coupled simulation, KS2005, was the starting point for all subsequent simulations. Data from the fully coupled and equilibrated PT simulations, 10xPT_C and 1xPT_C, was analyzed using the final 100 years of simulation. These simulations were integrated for 2700 years and 2050 years, respectively. The 1xPT_C simulation was motivated by the need to verify that high $\mathrm{CO}_{2}$ values, and not the paleogeography of the Permian world, was indeed the primary cause leading to anoxic ocean conditions found in KS2005 (10xPT_C). Figures from the CCSM3 present day control case (Yeager, et. al 2006), Mod_C, are also presented for reference and comparison and utilize the final 20 years of simulation. Equilibrium length for the modern control was 880 years. 
Clim. Past Discuss., doi:10.5194/cp-2017-42, 2017

Manuscript under review for journal Clim. Past

Discussion started: 3 April 2017

(C) Author(s) 2017. CC-BY 3.0 License.

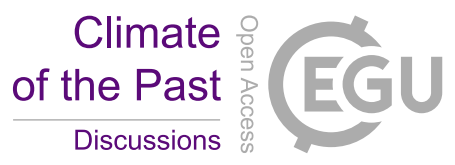

Results from the coupled equilibrium PT simulation, 10xPT_C and 1xPT_C, show noticeable shifts in the spatial location of the monsoonal precipitation. We postulate that these shifts are related to the corresponding changes in location of the SST warm pool found in the Paleo-Tethys Ocean. In the classic definition of a monsoon, the large land-sea temperature contrasts within the monsoon region are thought to be a primary forcing behind the monsoonal circulation, and, specifically for the

5 Pangean megamonsoon (Kutzbach and Gallimore, 1989). We conducted three additional simulations designed to test the land-sea contrast theory and land mass impact. The first experiment is a control. We employ the quicker and less expensive CAM3 (Community Atmosphere Model version 3), the atmospheric component to CCSM3, in fixed SST mode for two model simulations. A climatology of SSTs from the last 100 years of 10xPT_C were used to drive CAM3 with the exact same boundary and forcing to show that the fixed SST experiment reproduces the coupled experiment (10xPT_F). Second,

10 we removed the Cathyasian Peninsula in the northern hemisphere monsoonal region and drove CAM3 with the SSTs from 10xPT_C to test the sensitivity of the monsoonal precipitation to this land mass. Given that the intent is to simulate the atmosphere and test the geographic location of the monsoon in response to the SSTs in the absence of land, a fully coupled run was deemed unnecessary. However, our third experiment tests the sensitivity of monsoonal precipitation to the warm pool location within the Paleo-Tethys Ocean, (10xPT_C_NoIsle), where upper ocean currents play a key role. Here we

15 integrate a fully coupled simulation, which removes not only the Cathyasian Peninsula, but the Paleo-Tethys equatorial islands, (10xPT_C_NoIsle). The equatorial islands serve as a boundary and limit the warm pool location. In the absence of these land masses, we show that upper ocean currents are free to move the warm pool further westward, thus moving precipitation maxima with it. The fixed SST simulations, by definition, drive the atmosphere with equilibrated ocean surface temperatures and therefore only required 20 years of integration. In the coupled sensitivity run, because we are interested in

20 the upper ocean response only, the model was integrated for only 200 years, a sufficient length of time to establish stable results for depths down to $500 \mathrm{~m}$. Testing monsoonal precipitation's response to the warm pool by removing land masses has been studied in the modern context as well. Chao and Chen (2001) show the monsoonal precipitation in non-equatorial regions to be unaffected by removal of land masses. 
Clim. Past Discuss., doi:10.5194/cp-2017-42, 2017

Manuscript under review for journal Clim. Past

Discussion started: 3 April 2017

(C) Author(s) 2017. CC-BY 3.0 License.

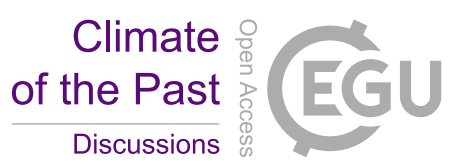

(c) (i)

\section{Data Availability}

Data from all simulations cited in this study are available on request to C. Shields, shields@ucar.edu.

\section{Acknowledgments}

We thank Bill Large, Gokhan Danabasoglu, and Steve Yeager (NCAR) for helpful conversations regarding the ocean

5 simulations. NCAR is sponsored by the The National Science Foundation. This work was supported through grants from the NSF EAR Sedimentary Geology and Paleoebiology program and the Heising-Simons Foundation.

\section{References}

Benton, M.J., and Twitchett, R.J., 2003, How to kill (almost) all life: The end-Permian extinction event: Trends in Ecology and Evolution, v. 18, p. 358-365.

10

Berner, R.A., 1999, Atmospheric oxygen over Phanerozoic time: National Academy of Sciences Proceedings, v. 96, p. $10,955-10,957$.

Black, Benjamin A., Linda T. Elkins-Tanton, Michael C. Rowe, Ingrid Ukstins Peate, Magnitude and consequences of 15 volatile release from the Siberian Traps, Earth and Planetary Science Letters 317-318 (2012) 363-373, doi: 10.1016/j.eps1.2011.12.001.

Collins, W.D., C.M. Bitz, M. Blackmon, G.B. Bonan, C.S. Bretherton, J.A. Carton, P. Chang, S. Doney, J.J. Hack, T. Henderson, J.T. Kiehl, W.G. Large, D. McKenna, B.D. Santer, and R. Smith, 2006: The Community Climate System Model, 20 Version 3.

J. Climate, Special Issue, Vol 19, No 11.

Erwin, D.H., 1993, The great Paleozoic crisis, life and death in the Permian: New York, Columbia University Press, 327 p. 
Clim. Past Discuss., doi:10.5194/cp-2017-42, 2017

Manuscript under review for journal Clim. Past

Discussion started: 3 April 2017

(c) Author(s) 2017. CC-BY 3.0 License.

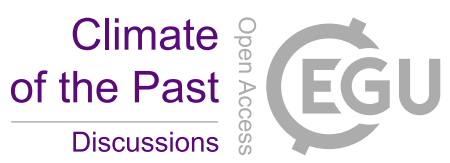

Fluteau, F., Bessea, J., Broutinb, J., Ramsteinc, G., 2001, The Late Permian climate. What can be inferred from climate modelling concerning Pangea scenarios and Hercynian range altitude?, Paleogeography, Paleoclimatology, Paleoecology, 167 (2001) 39-71.

5

Heavens, N. G., N. M. Mahowald, G. S. Soreghan, M. J. Soreghan, and C. A. Shields, 2015: A model-based evaluation of tropical climate in Pangaea during the late Palaeozoic icehouse. Palaeogeography, Palaeoclimatology, Palaeoecology, 426, 109-127, doi: 10.1016/j.palaeo.2015.02.024.

10 Jochum, M., B. Fox-Kemper, P. H. Molnar, and C. Shields, 2009, Differences in the Indonesian seaway in a coupled climate model and their relevance to Pliocene climate and El Nino, Paleoceanography, doi:10.1029/2008PA001678

Kidder, D.L., and Worsley, T.R., 2004, Causes and consequences of extreme Permo-Triassic warming to globally equable climate and relation to the Permo-Triassic extinction and recovery: Palaeogeography, Palaeoclimatology, Palaeoecology, v.

15203 , p. 207-237.

Kiehl, J.T., Shields,C.A., 2005, Climate Simulation of the Latest Permian: Implications for Mass Extinction, Geology, vol 33, no 9, p.757-760,doi: 10.1130/G21654.1.

20 Kiehl JT, Shields CA. 2013 Sensitivity of the Palaeocene-Eocene Thermal Maximum climate to cloud properties. Phil Trans R Soc A 371: 20130093. http://dx.doi.org/10.1098/rsta.2013.0093.

Kutzbach, J.E. and R.G. Gallimore (1989). Pangaean Climates: Megamonsoons of the Megacontinent. Journal of Geophysical Research 94, 3341-3358. 
Clim. Past Discuss., doi:10.5194/cp-2017-42, 2017

Manuscript under review for journal Clim. Past

Discussion started: 3 April 2017

(c) Author(s) 2017. CC-BY 3.0 License.

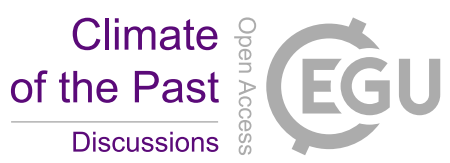

(c) (i)

Kutzback, J.E. and Ziegler, A.M., 1993, Simulation of Late Permian Climate and Biomes with an Atmosphere-Ocean Model:

Comparisons with Observations. Phil. Trans. R. Soc. Lond. B 28 August 1993 vol. 341 no. 1297 327-340

Lamarque, J.-F.,Kiehl, J.T.,Shields,C.A.,Boville,B.A.,Kinnison,D.E.,2006, Modeling the Response to Changes in

5 Tropospheric Methane Concentration: Application to the Permian-Triassic Boundary, Paleooceanography , 21,

PA3006,doi:10.1029/2006PA001276.

Liu.,Z., Otto-Bliesner, B., Kutzbach, J., Li, L., and Shields, C. , 2003, Coupled Climate Simulations of the Evolution of Global Monsoons in the Holocene, Journal of Climate, Vol 16, pp. 2472-2490.

10

Meehl, Gerald A., Julie M. Arblaster, David M. Lawrence, Anji Seth, Edwin K. Schneider, Ben P. Kirtman, Dughong Min, 2006: Monsoon Regimes in the CCSM3. J. Climate, 19, 2482-2495. doi: http://dx.doi.org/10.1175/JCLI3745.1

Renne, P.R., Zichao, Z., Richards, M.A., Black, M.T., and Basu, A.R., 1995, Synchrony and causal relations between 15 Permian-Triassic boundary crises and Siberian flood volcanism: Science, v. 269, p. 1413-1416.

Rowe, C. M., Loope, D. B., Oglesby, R. J., Van der Voo, R., Broadwater, C.E., 2007, Inconsistencies Between Pangean Reconstructions and Basic Climate Controls, Science,

Vol. 318 no. 5854 pp. 1284-1286 DOI: 10.1126/science.1146639

20

Wignall, P.B., and Twitchett, R.J., 1996, Oceanic anoxia and the end Permian mass extinction: Science, v. 272, p. 11551158.

Winguth, A., Winguth, C., Precession-driven monsoon variability at the Permian-Triassic Implications for anoxia and the 25 mass extinction, Glob. Planet. Change (2012), doi: 10.1016/j.gloplacha.2012.06.006 
Clim. Past Discuss., doi:10.5194/cp-2017-42, 2017

Manuscript under review for journal Clim. Past

Discussion started: 3 April 2017

(C) Author(s) 2017. CC-BY 3.0 License.

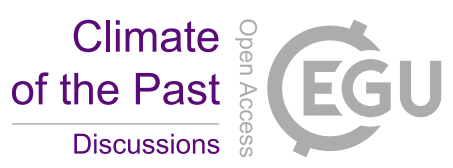

(c) (i)

Yeager, S.G., Shields, C.A., Large, W.G., Hack,J.J., 2006, The Low Resolution CCSM3, Journal of Climate, Special Issue, Vol 19, No 11, pp 2545-2566.

5 Yin, X., A. Gruber, and P. Arkin, 2004: Comparison of GPCP and CMAP merged guage-satellite monthly precipitation products for the period 1970-2001., J. Hydrometer, 5, 1207-1222.

Zhou, J., Poulsen, C. J., Rosenbloom, N., Shields, C., and Briegleb, B., 2012: Vegetation-climate interactions in the warm mid-Cretaceous, Clim. Past, 8, 565-576, doi:10.5194/cp-8-565-2012.

10

15 
Clim. Past Discuss., doi:10.5194/cp-2017-42, 2017

Manuscript under review for journal Clim. Past

Discussion started: 3 April 2017

(c) Author(s) 2017. CC-BY 3.0 License.

\section{Climate \\ of the Past \\ Discussions}

(c) (i)

Table 1: CCSM3 model experiments analyzed in this paper. Fixed sea surface temperature (SST) simulations utilize interactive atmosphere and land components with SST derived from KS2005. All other atmosphere and land forcings are the same as KS2005.

\begin{tabular}{|l|l|l|l|}
\hline Identifier & Model Components & $\mathbf{C O}_{2}$ Value & Forcing Description \\
\hline 10xPT_C & Fully Coupled & $3550 \mathrm{ppmv}$ & KS2005 \\
\hline 1xPT_C & Fully Coupled & $355 \mathrm{ppmv}$ & KS2005 except $\mathrm{CO}_{2}$ level \\
\hline Mod_C & Fully Coupled & $355 \mathrm{ppmv}$ & Yeager et al 2006 \\
\hline 10xPT_F & Fixed SST & $3550 \mathrm{ppmv}$ & SST derived from KS2005 \\
\hline 10xPT_F_NoPen & Fixed SST & $3550 \mathrm{ppmv}$ & 1 10xPT_F except no Cathyasian \\
& & & Peninsula \\
\hline 10xPT_C_NoIsle & Fully Coupled & $3550 \mathrm{ppmv}$ & 10xPT_F_NoPen except no equatorial \\
& & & islands and no Cathyasian Peninsula \\
\hline
\end{tabular}

5 
Clim. Past Discuss., doi:10.5194/cp-2017-42, 2017

Manuscript under review for journal Clim. Past

Discussion started: 3 April 2017

(c) Author(s) 2017. CC-BY 3.0 License.

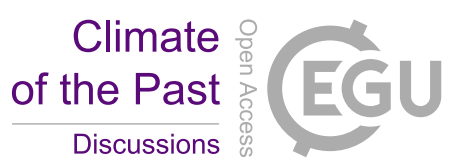

(c) $\underset{\mathrm{BY}}{(\mathrm{i})}$

Table 2: KS 2005 forcing data. Boundary conditions for all PT simulations employ paleogeography and paleotopography by

D. Rowley (http://geosci.uchicago.edu/ rowley/Rowley/Paleogeographic_Atlas_Project.html). Modifications for

10x_PT_F_NoPen and 10x_PT_C_NoIsle were made by the authors of this paper to test sensitivity of the monsoon to geography. All trace gas concentrations are in ppmv.

\begin{tabular}{l|llllll}
\hline & $\mathrm{CO} 2$ & $\mathrm{CH} 4$ & $\mathrm{~N} 2 \mathrm{O}$ & $\mathrm{S} 0$ & Eccentricity & Obliquity(Degrees) \\
\hline Value & 3550 & 0.7 & 0.275 & 1338 & 0. & 23.5 \\
\hline
\end{tabular}

10

15 
Clim. Past Discuss., doi:10.5194/cp-2017-42, 2017

Manuscript under review for journal Clim. Past

Discussion started: 3 April 2017

(c) Author(s) 2017. CC-BY 3.0 License.

\section{Climate of the Past \\ Discussions}

(c) (i)

Figure 1: Surface temperature $\left({ }^{\circ} \mathrm{C}\right)$ for $10 \mathrm{X}$ Coupled DJF and JJA (upper panels, $1 X$ Coupled DJF and JJA (middle panels), and $P D$ Control DJF and JJA (lower panels). Plots are centered on $0^{\circ} \mathrm{N}$ and $0^{\circ} \mathrm{E}$ and are spaced every 30 degrees.

5
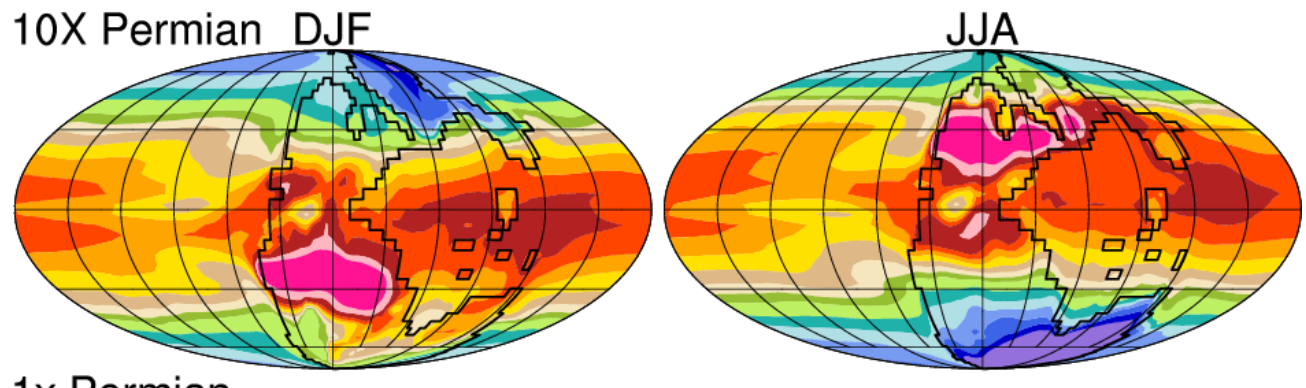

1x Permian
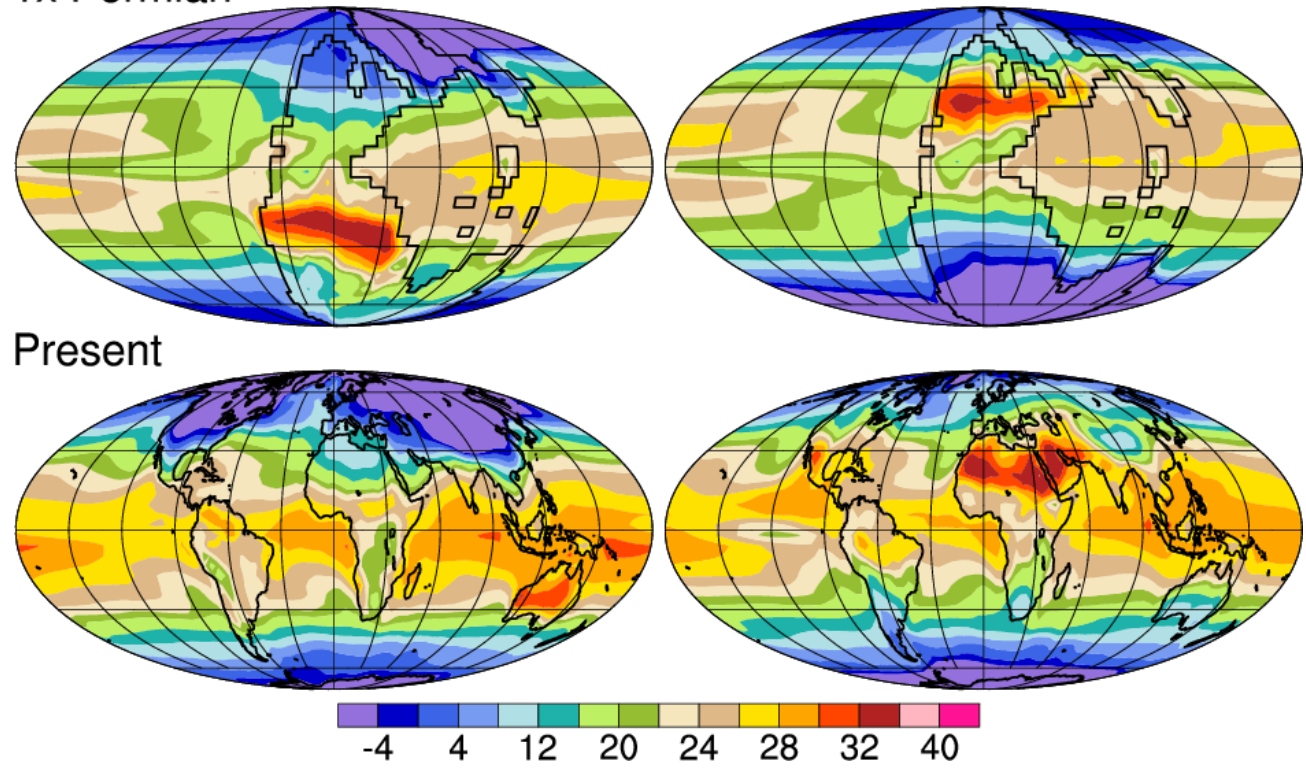
Clim. Past Discuss., doi:10.5194/cp-2017-42, 2017

Manuscript under review for journal Clim. Past

Discussion started: 3 April 2017

(c) Author(s) 2017. CC-BY 3.0 License.

\section{Climate of the Past \\ Discussions}

(c) (i)

Figure 2: Annual cycle of precipitation (mm/day) for monsoon regions for $10 X$ Coupled (upper left), $1 X$ Coupled (upper right), PD Control (lower left) and GCPC observations (lower left).
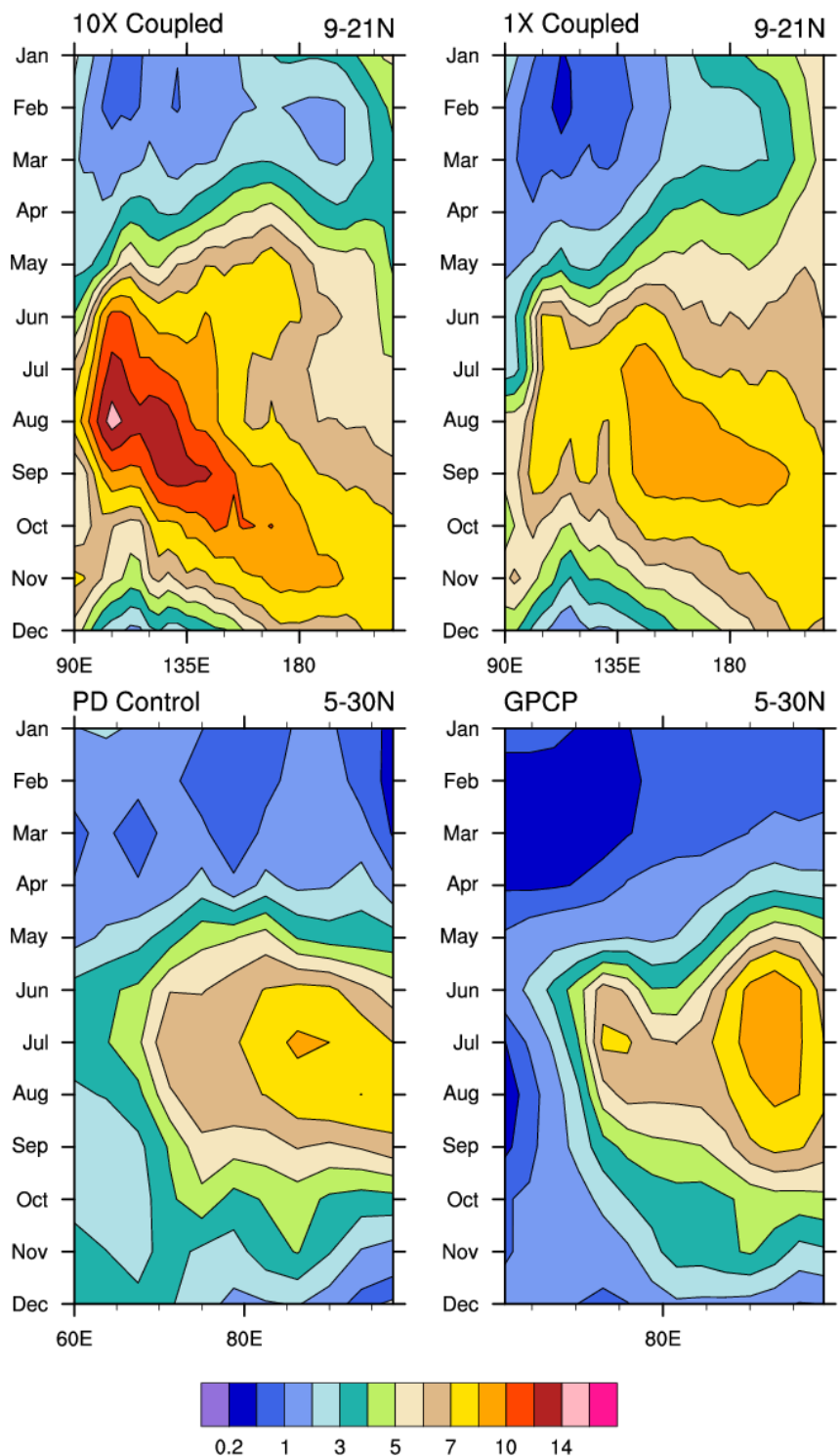
Clim. Past Discuss., doi:10.5194/cp-2017-42, 2017

Manuscript under review for journal Clim. Past

Discussion started: 3 April 2017

(c) Author(s) 2017. CC-BY 3.0 License.

\section{Climate of the Past \\ Discussions}

(c) (1)

Figure 3: Sea surface temperature $\left({ }^{\circ} \mathrm{C}\right)$ annual cycle for Permian monsoon regions for $10 X$ Coupled (left) and $1 x$ Coupled (right).

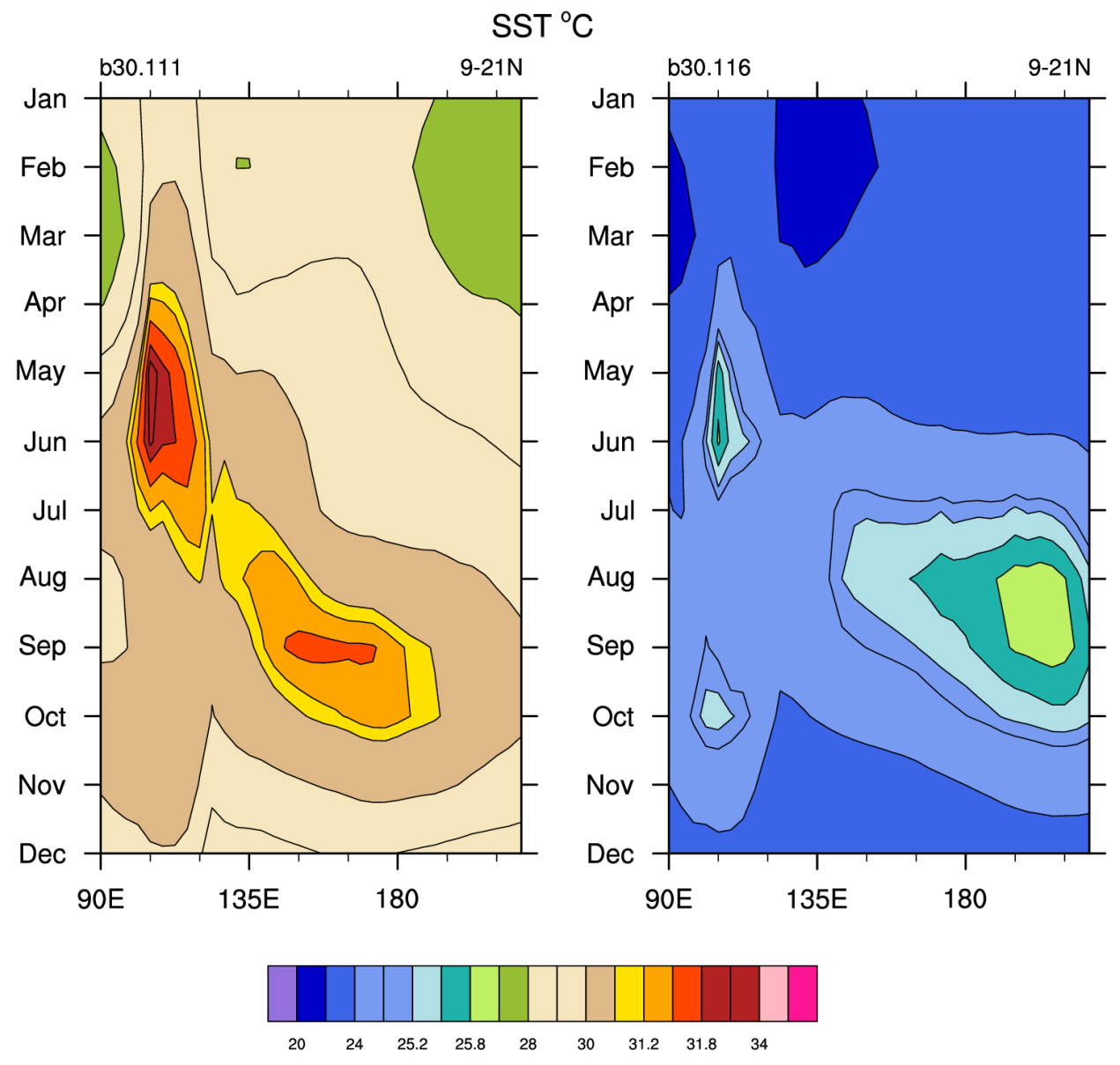


Clim. Past Discuss., doi:10.5194/cp-2017-42, 2017

Manuscript under review for journal Clim. Past

Discussion started: 3 April 2017

(c) Author(s) 2017. CC-BY 3.0 License.

\section{Climate of the Past \\ Discussions}

(c) (1)

Figure 4: $100 \mathrm{~m}$ vertical velocity $\left(10^{-4} \mathrm{x} \mathrm{cms}^{-1}\right)$ for $10 X$ Coupled DJF and JJA (left panels), $1 X$ Coupled DJF and JJA (right panels). Plots are centered on $0^{\circ} \mathrm{N}$ and $0^{\circ} \mathrm{E}$ and are spaced every 30 degrees.

DJF 10X Coupled

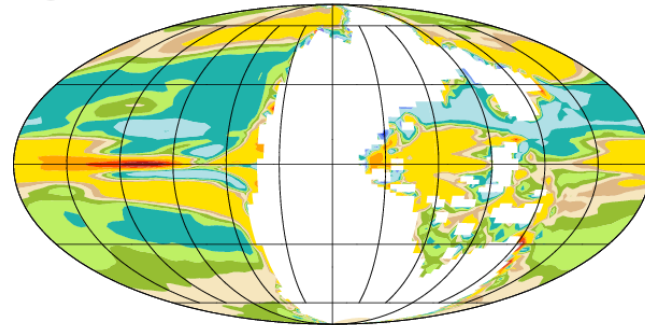

JJA

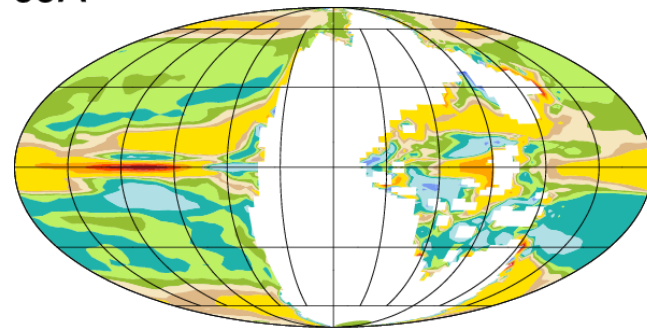

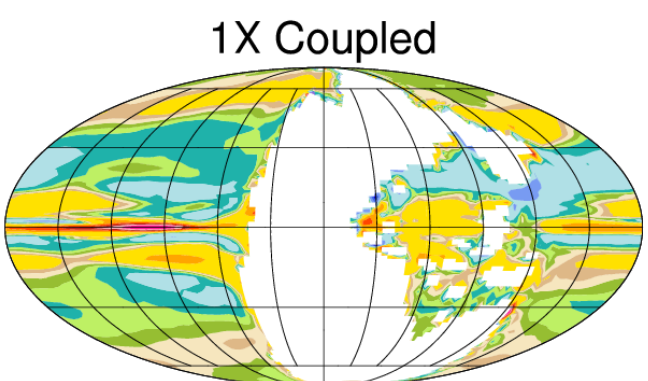

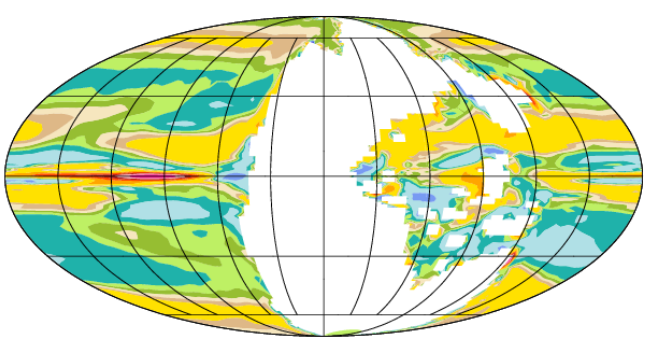

5

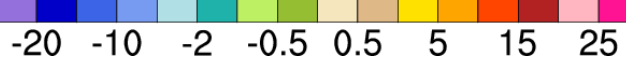

10 
Clim. Past Discuss., doi:10.5194/cp-2017-42, 2017

Manuscript under review for journal Clim. Past

Discussion started: 3 April 2017

(c) Author(s) 2017. CC-BY 3.0 License.

\section{Climate of the Past \\ Discussions}

(c) (1)

Figure 5: Precipitation (mm/day) for $10 X$ NoPen DJF and JJA (left panels) and 10X Atm DJF and JJA (right panels). Plots are centered on $0^{\circ} \mathrm{N}$ and $0^{\circ} \mathrm{E}$ and are spaced every 30 degrees.

DJF 10X Remove Land

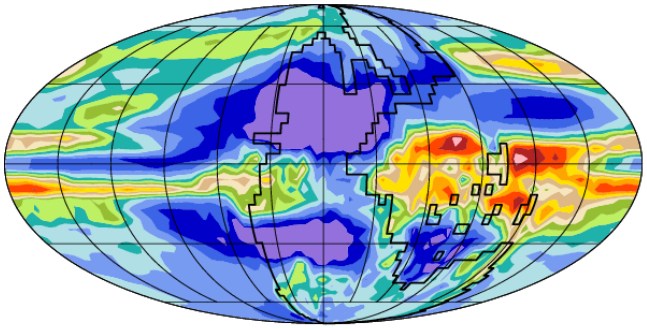

JJA
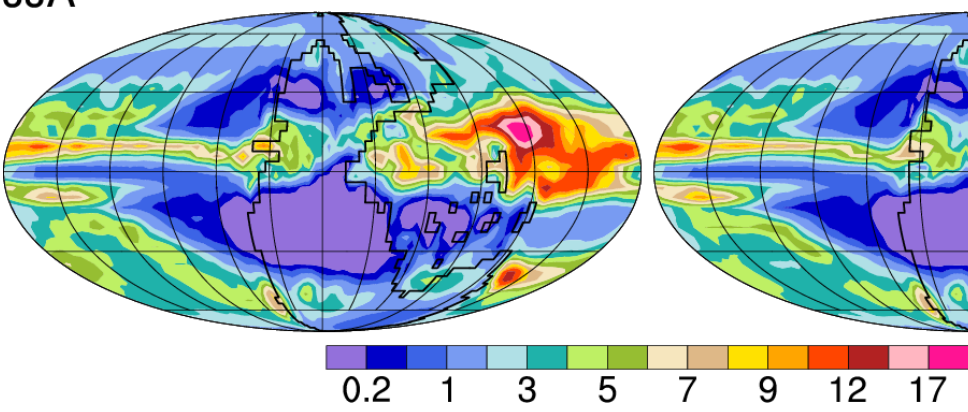

10X Control
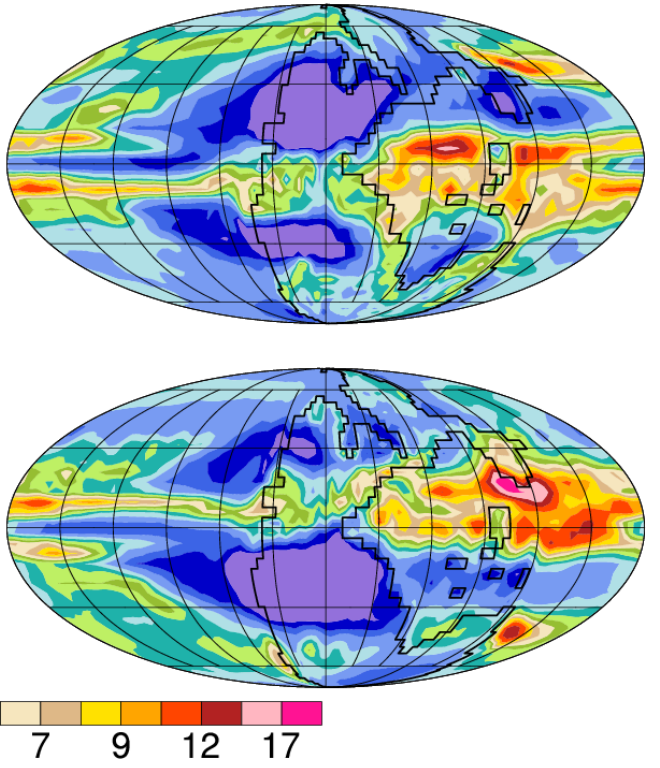

5 
Clim. Past Discuss., doi:10.5194/cp-2017-42, 2017

Manuscript under review for journal Clim. Past

Discussion started: 3 April 2017

(C) Author(s) 2017. CC-BY 3.0 License.

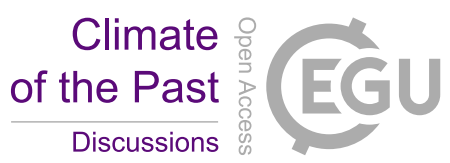

(c) (i)

Figure 6: JJA-DJF $850 \mathrm{mb}$ velocity potential $\left(\mathrm{x} 10 \mathrm{e}^{5} \mathrm{~m}^{2} \mathrm{~s}^{-1}\right)$ and divergent wind vectors for $10 X$ Coupled (upper) $10 X$ Atm (middle), and $10 X$ NoPen (lower panel). Plots are centered on $0^{\circ} \mathrm{N}$ and $0^{\circ} \mathrm{E}$ and are spaced every 30 degrees.

5

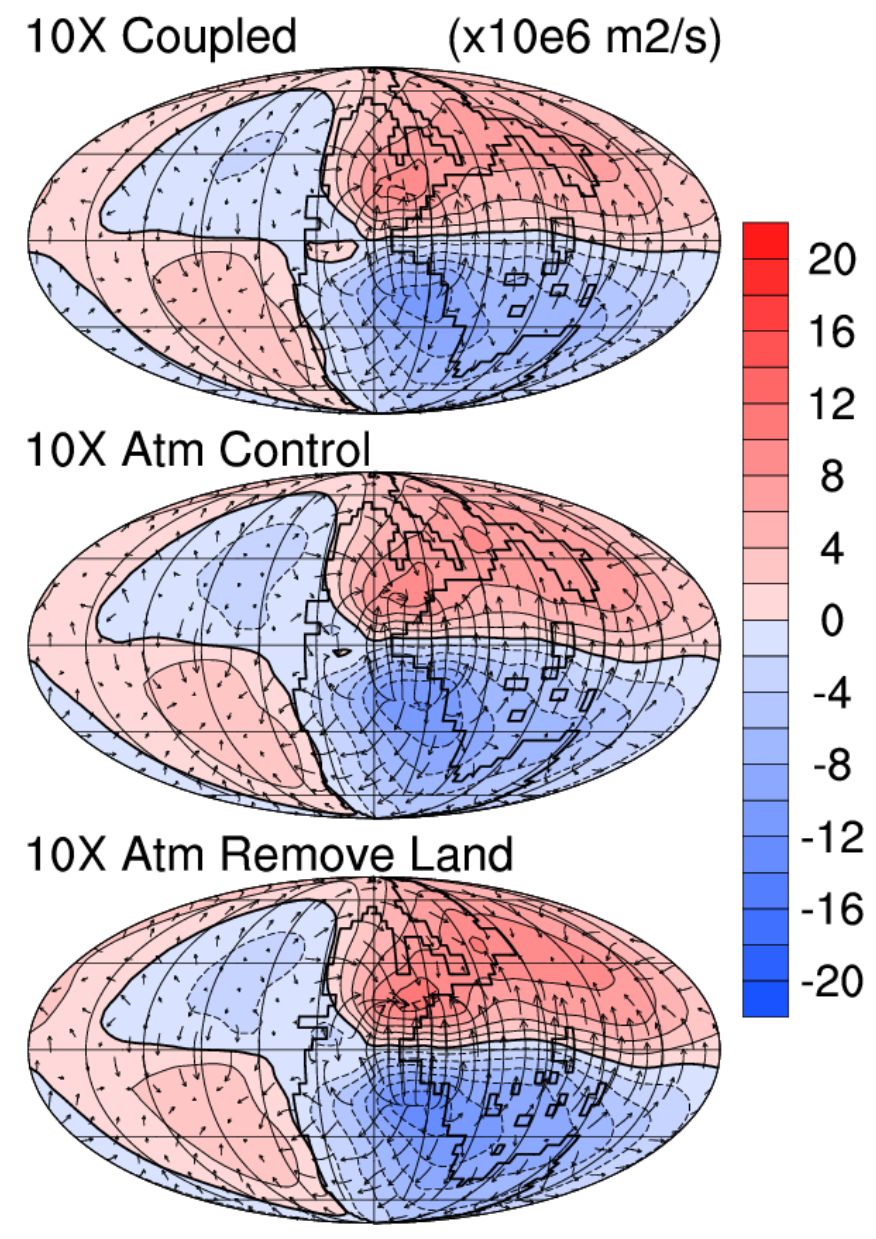


Clim. Past Discuss., doi:10.5194/cp-2017-42, 2017

Manuscript under review for journal Clim. Past

Discussion started: 3 April 2017

(c) Author(s) 2017. CC-BY 3.0 License.

\section{Climate of the Past \\ Discussions}

(c) $\underset{\mathrm{BY}}{(i)}$

Figure 7: Surface temperature $\left({ }^{\circ} \mathrm{C}\right)$ for $10 X$ Coupled and $10 X$ NoIsle (upper and middle panels, respectively), and precipitation difference (mm/day) for $10 X$ NoIsle - 10X Coupled (lower panel).
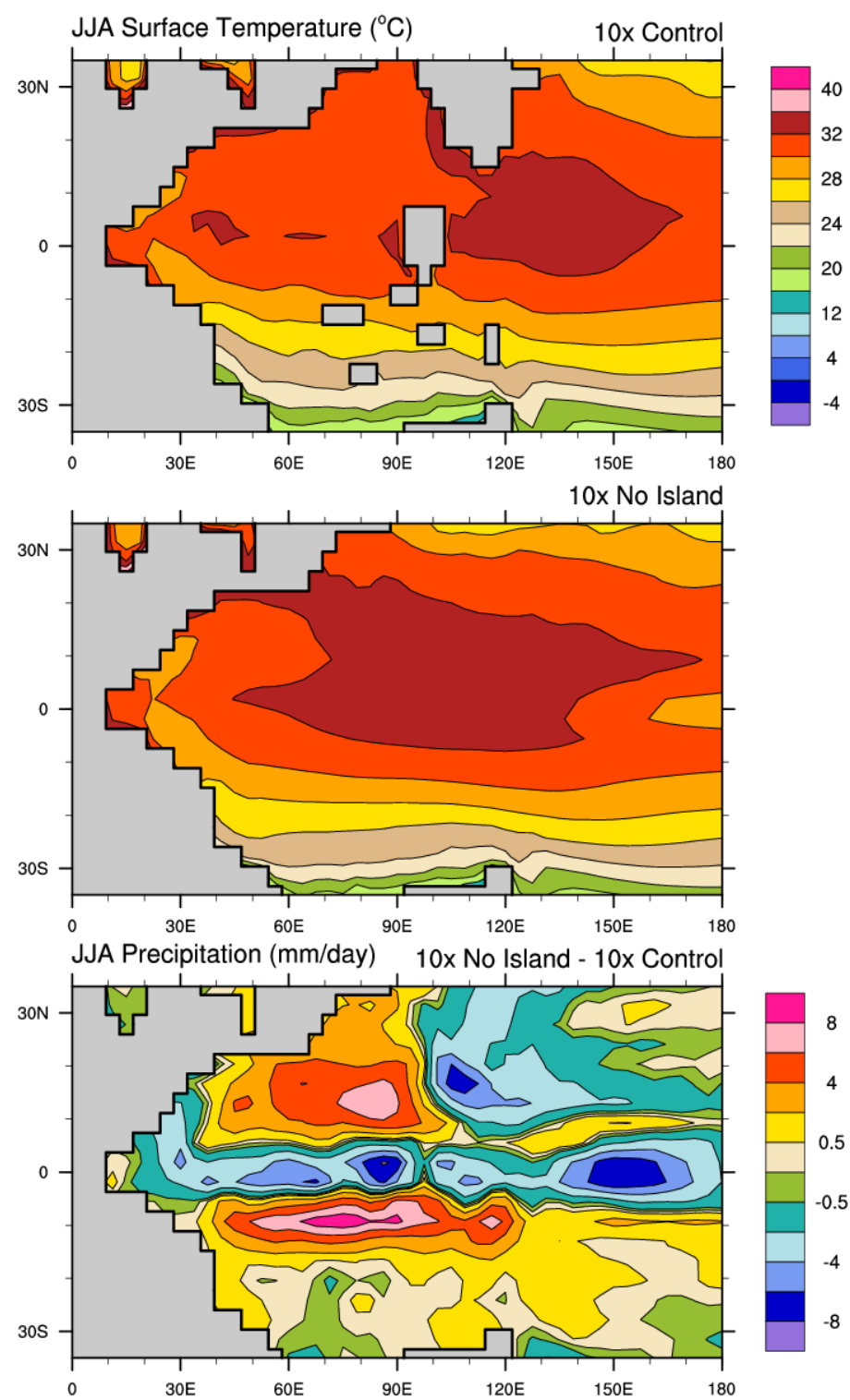
Clim. Past Discuss., doi:10.5194/cp-2017-42, 2017

Manuscript under review for journal Clim. Past

Discussion started: 3 April 2017

(c) Author(s) 2017. CC-BY 3.0 License.

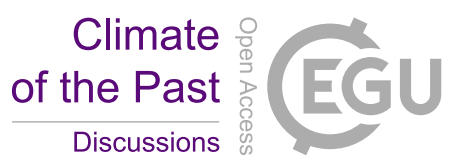

(c) (i)

Figure 8: Sea surface temperature $\left({ }^{\circ} \mathrm{C}\right)$ for an expanded Permian monsoon region for $10 X$ Coupled (left) and $10 X$ NoIsle (right panel).

5

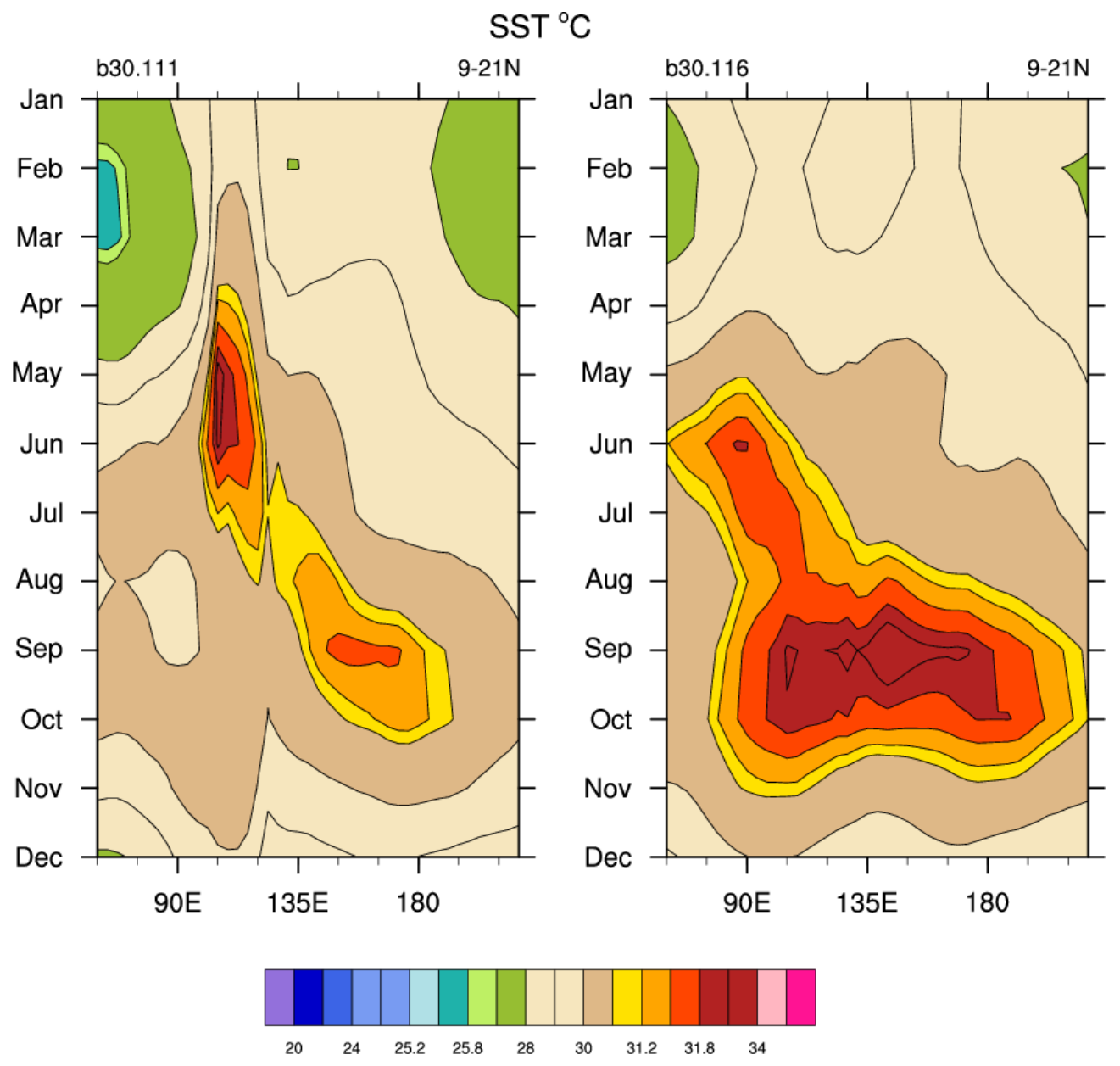


Clim. Past Discuss., doi:10.5194/cp-2017-42, 2017

Manuscript under review for journal Clim. Past

Discussion started: 3 April 2017

(c) Author(s) 2017. CC-BY 3.0 License.
Climate of the Past

Discussions

Figure 9: Precipitation annual cycle (mm/day) for the $10 X$ NoIsle expanded monsoon region.

Precipitation ( $\mathrm{mm} / \mathrm{day})$

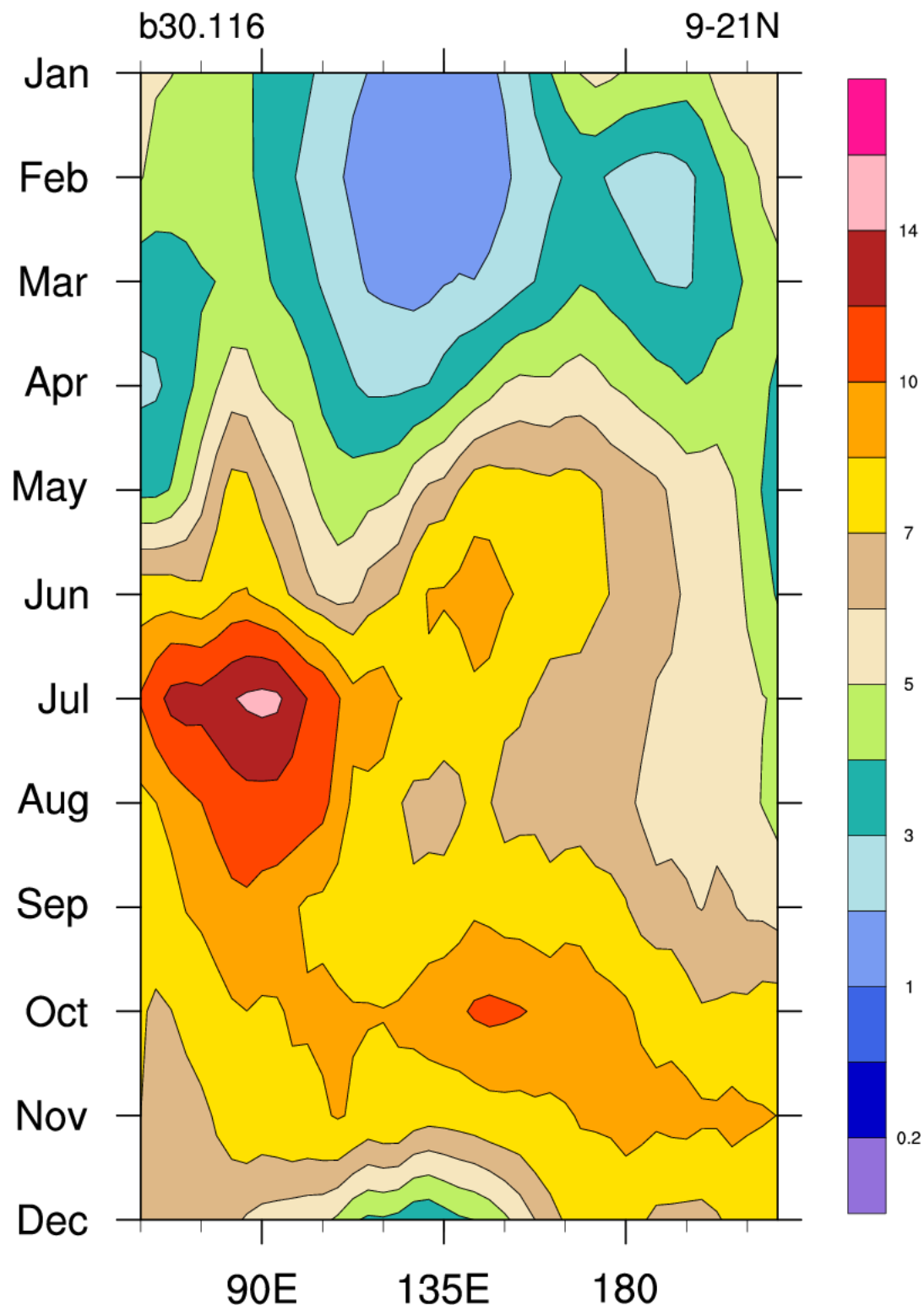


Clim. Past Discuss., doi:10.5194/cp-2017-42, 2017

Manuscript under review for journal Clim. Past

Discussion started: 3 April 2017

(c) Author(s) 2017. CC-BY 3.0 License.

\section{Climate of the Past \\ Discussions}

(c) (i)

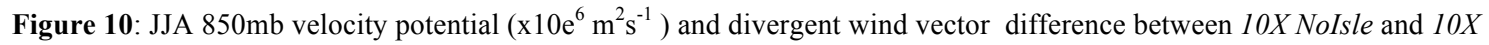
Coupled. Plot is centered on $0^{\circ} \mathrm{N}$ and $0^{\circ} \mathrm{E}$ and spaced every 30 degrees.

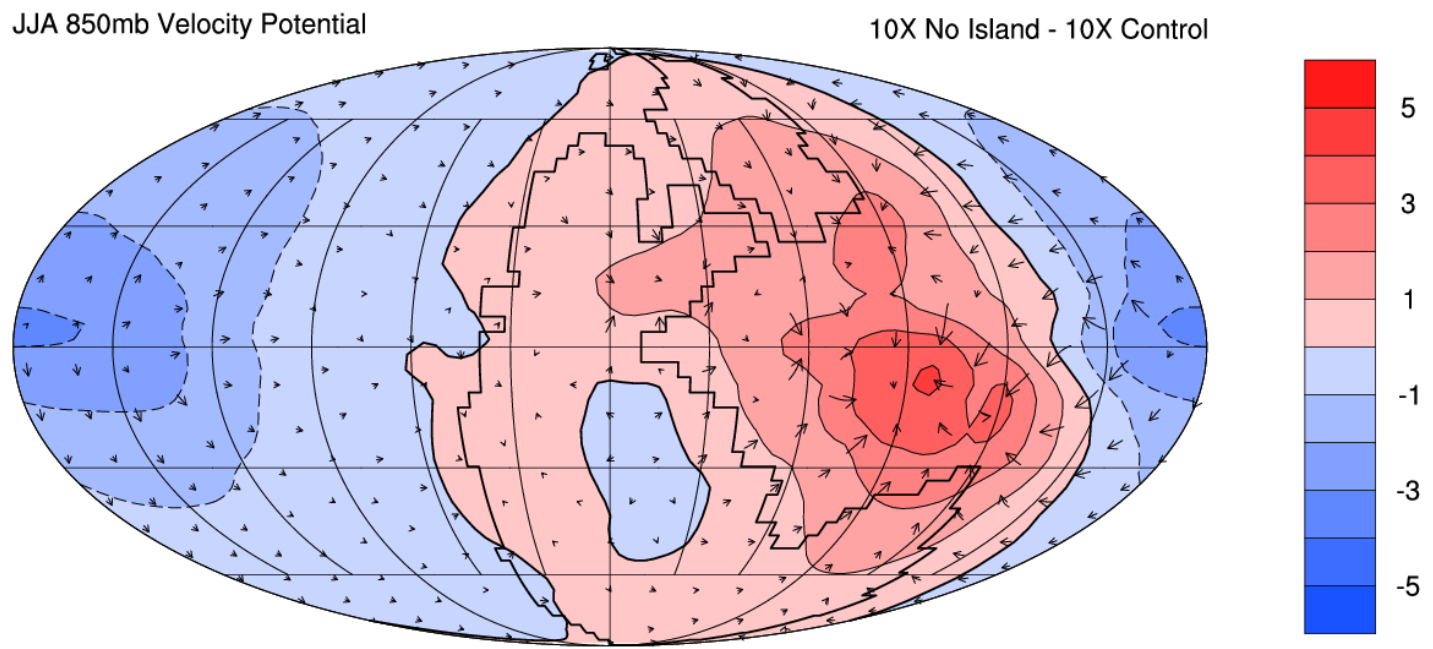


Clim. Past Discuss., doi:10.5194/cp-2017-42, 2017

Manuscript under review for journal Clim. Past

Discussion started: 3 April 2017

(c) Author(s) 2017. CC-BY 3.0 License.

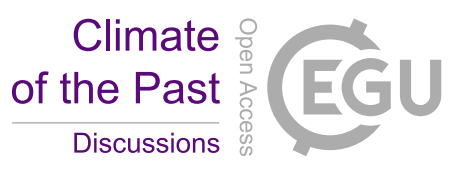

(c) $\underset{\mathrm{BY}}{(i)}$

Figure 11: Annual zonal velocity $\left(\mathrm{cms}^{-1}\right)$ averaged about the equator for the upper Panthalassic Ocean for 10X Coupled (upper panel) and 10X NoIsle (lower panel). White areas represent land.
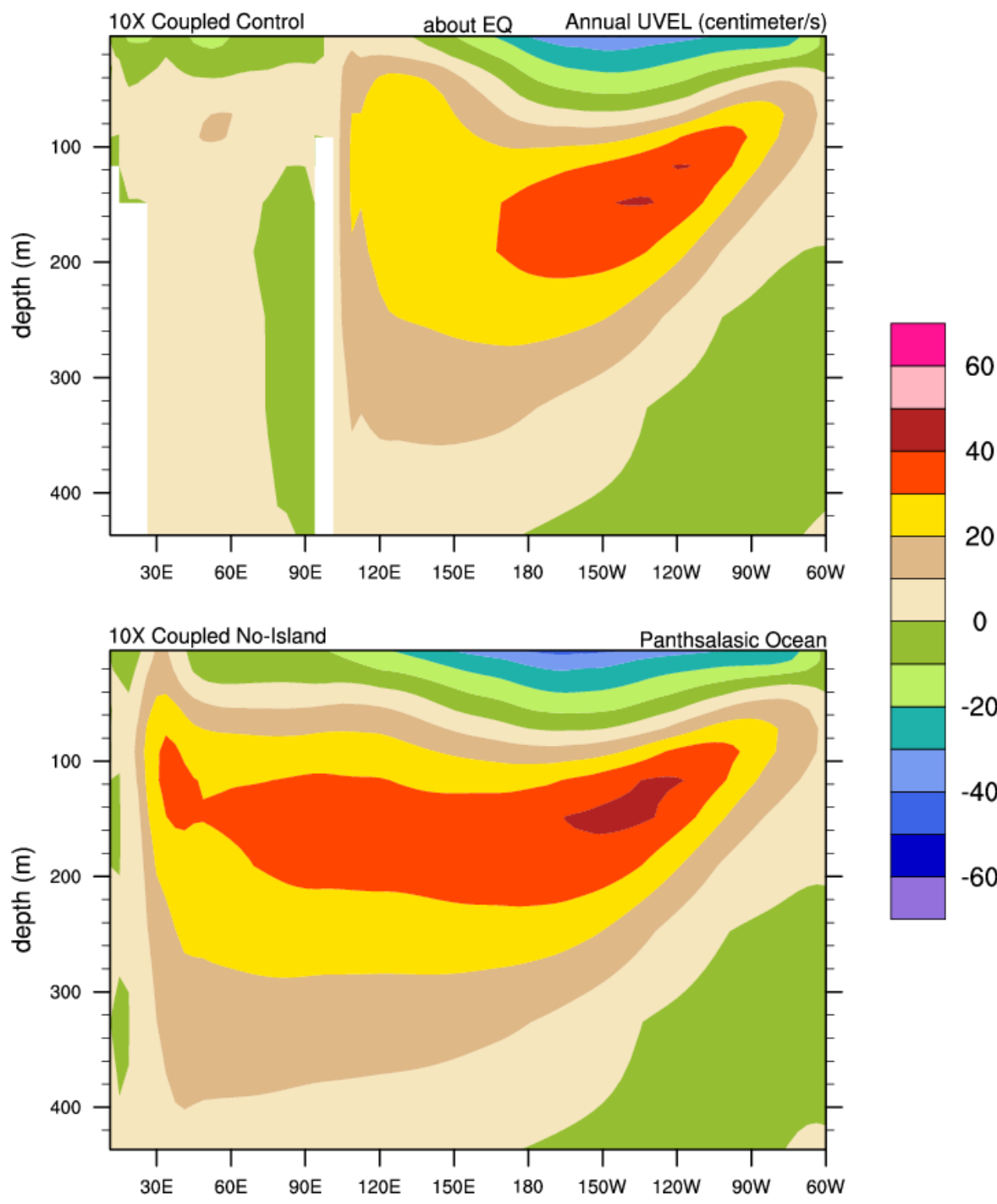

0 